\title{
Do Parent units benefit from Reverse Knowledge
}

\section{Transfer?}

\author{
Smitha R. Nair \\ Norwich Business School \\ University of East Anglia, Norwich Research Park \\ Norwich, NR4 7TJ \\ United Kingdom \\ S.Ravindranathan-Nair@uea.ac.uk \\ Mehmet Demirbag* \\ Essex Business School, \\ University of Essex, Elmer Approach \\ Southend-on-Sea, SS1 1LW \\ United Kingdom \\ mdemirc@essex.ac.uk \\ Kamel Mellahi \\ Warwick Business School \\ University of Warwick \\ Coventry, CV4 7AL \\ United Kingdom \\ Kamel.Mellahi@wbs.ac.uk \\ Kishore Gopalakrishna Pillai \\ Norwich Business School \\ University of East Anglia, Norwich Research Park \\ Norwich, NR4 7TJ \\ United Kingdom \\ K.Gopalakrishna-Pillai@uea.ac.uk
}

* Corresponding Author 


\title{
Do Parent units benefit from Reverse Knowledge
}

\section{Transfer?}

\begin{abstract}
Emerging market multinationals resort to knowledge acquisitions from their overseas subsidiaries to springboard and realise their global ambitions. Drawing from the knowledgebased view and social capital perspective, this study explores the effects of organisational collaboration and tacitness on multiple dimensions of reverse knowledge transfer (RKT). Data were collected through a survey, from senior and middle level managers of parent Indian multinationals, pertaining to RKT from their overseas subsidiaries. The hypotheses are analysed using PLS modelling. The results demonstrate positive effects between the extent and benefits of RKT. Collaboration was found to have a positive influence on both dimensions of RKT. Tacitness also has a positive impact on the benefits from RKT. The implications of the findings and the limitations of the study are discussed along with suggestions for future research.
\end{abstract}

Keywords: Reverse knowledge transfer, collaboration, tacit, emerging market, India 


\section{Introduction}

Knowledge transfers, especially involving cross border interactions of multinational enterprises' (MNEs) units have attracted considerable attention from international business and management scholars. By and large these studies (Li, 2005; Minbaeva et al., 2003; Minbaeva 2005; Tran, Mahnke and Ambos, 2010) are focussed on the parent units transferring their knowledge to their acquired overseas subsidiaries (conventional or primary knowledge transfers), so that they are able to perform their envisaged role within the MNE network (Ambos, Ambos and Schlegelmilch, 2006). This is not surprising because these overseas acquisitions were conventionally performed by the very well-equipped and competent Western MNEs from the developed economies (DMNEs) and more often than not, their subsidiaries lagged behind their advanced parent units when it came to strategic resources and state-of-the-art capabilities. However, as these subsidiaries learn and develop their capabilities, parent units start recognising their subsidiaries and subsequently tap into the subsidiary knowledge (Denrell, Arvidsson and Zander, 2004) to leverage their resources, which has fuelled the interest in reverse knowledge transfers (RKT).

Unlike the DMNEs, the acquisitions of emerging market MNEs (EMNEs), especially in the developed markets, are driven by knowledge seeking motives to a large extent (Bangara, Freeman and Schroder, 2012; Buckley et al., 2016a; Jormanainen and Koveshnikov, 2012; Kedia, Gaffny and Clampit, 2012; Luo and Tung, 2007; Mathews, 2006; Thite et al., 2015; Wilkinson, Wood and Demirbag, 2014). As latecomers, these acquisitions are vital for them to rapidly catch up with their global competitors (springboard). This is because, as latecomers, they are also likely to lag behind their more advanced competitors in the developed markets in terms of the strategic resources and capabilities (Khan and Nicholson, 2014). The strategic asset seeking behaviour of EMNEs (via overseas acquisitions) help them 
attain the much needed competitive edge in international markets. EMNEs have more overseas subsidiaries that engage in RKT when compared to DMNEs (Giuliani et al., 2014). The DMNEs, on the other hand, have more passive subsidiaries engaging primarily with conventional knowledge transfers. This body of evidence lends further support to the argument that EMNEs attempt knowledge acquisition via RKT and hence it is crucial that we further understand the knowledge pursuits of EMNEs and the benefits they accrue from the same. Hence, this study seeks to explore RKT in an emerging market context, more specifically dealing with Indian MNEs and their overseas subsidiaries.

Prior studies on RKT (Ambos, Ambos and Schlegelmilch, 2006; Hakanson and Nobel, 2001; Mudambi, Piscitello and Rabbiosi, 2014; Najafi-Tavani, Giroud and Sinkovics, 2012; Pereira, Munjal and Nandakumar, 2016; Rabbiosi, 2011; Rabbiosi and Santangelo, 2013; Yang, Mudambi and Meyer, 2008) have dealt largely with DMNEs focusing on the effects of organisational mechanisms or firm level factors. Some of these studies have also highlighted the significance of focusing on the benefits or utilisation of RKT (Ambos, Ambos and Schlegelmilch, 2006; Yang, Mudambi and Meyer, 2008) rather than on the extent of RKT, which was the conventional approach followed by most scholars. This is based on the premise that not all knowledge transfer (KT) that occurs is likely to benefit the recipient unit (Ambos, Ambos and Schlegelmilch, 2006), which is the parent unit in the case of RKT. However, there is a dearth of studies that investigate the potential links between the extent of RKT and the benefits that parent units derive from it. It is vital to understand the extent to which the parent units actually benefit from the RKT, since these transfers are costly and involve significant investments in terms of resources and time. The first contribution of this study is that it analyses the potential links between the two dimensions of RKT viz. extent of 
RKT and the benefits that parent units derive from the same, indicating the effectiveness of such transfers.

Knowledge attributes like ambiguity, complexity, stickiness and tacitness have always been considered as inhibitors to KT (Simonin, 1999; Szulanski, 1996; Szulanski, Cappetta and Jensen, 2004; Zander and Kogut, 1995). Studies on RKT have seldom investigated the effects of knowledge attributes on RKT, except for the effects of relevance of knowledge (Yang, Mudambi and Meyer, 2008). The tacitness of knowledge (Polanyi, 1962) is very crucial and is central to the discussions pertaining to the knowledge-based view (KBV) of the firm (Grant, 1996a). Tacit knowledge has been viewed as a vital source of competitive advantage for firms simply because of the fact that it is embedded deep within individuals and organisations (Nelson and Winter, 1982; Reed and DeFillippi, 1990), thus making it more inimitable, valuable and beneficial (Barney, 1991; Grant, 1996a), but difficult to transfer (Grant, 1996a; Park, Vertinsky and Becerra, 2015). In this context, it is vital to understand the effects of tacitness on both the extent of RKT as well as the benefits derived from RKT to reveal differential effects if any. The second contribution of this study is that it investigates the effects of tacitness on the two dimensions of RKT (extent and benefits).

$\mathrm{KBV}$ of the firm also discusses the need to observe tacit knowledge through its application in order to better comprehend it (Grant, 1996a; Kogut and Zander, 1992). It is also vital for individuals to have shared understanding and experiences while sharing tacit knowledge (Nonaka and Takeuchi, 1995). Inter-organisational collaboration facilitates such personal interactions and creation of shared mental models, which are essential to transferring tacit knowledge (Dhanaraj et al., 2004; Nonaka, 1991). In addition, the social capital perspective (Nahaphiet and Ghoshal, 1998; Tsai and Ghoshal, 1998) stresses on the significance of aspects like shared vision, trust, mutual respect, collaboration and commitment, which 
facilitate KT (Li, 2005; Muthuswamy and White, 2005; Yamao, de Cieri and Hutchings, 2009). However, there is a dearth of empirical studies that explore the joint effects of interorganisational collaboration and tacitness on RKT. Additionally, the influence of collaboration on the two dimensions of RKT (extent and benefits) still remains overlooked. Hence the final contribution of this study is that it explores the inter-linkages between tacitness, collaboration and the two dimensions of RKT in a joint model.

\section{Theoretical Background}

\section{Reverse Knowledge Transfer}

The knowledge transfer literature has a fair share of studies devoted to the conventional knowledge transfer, i.e. flow of knowledge from parent to subsidiaries. Compared to conventional KT, only a few studies (c.f Ambos, Ambos and Schlegelmilch, 2006; Hakanson and Nobel, 2001; Mudambi, Piscitello and Rabbiosi, 2014; Najafi-Tavani, Giroud and Sinkovics, 2012; Rabbiosi, 2011; Yang, Mudambi and Meyer, 2008) have focussed on RKT, i.e. flow of knowledge from subsidiaries to parent. The conventional flows, often termed as competence exploitation attempts (Awate, Larsen and Mudambi, 2015) adopted predominantly by DMNEs, are more "teaching flows" intended to upgrade the subsidiary capabilities. The parent DMNEs in such cases are likely to be relatively more competent (with superior capabilities) than their subsidiaries. On the other hand, RKT specifically in an emerging market context, is more of an imitation-driven catch-up strategy, which is also referred to as an asset exploration attempt. Here the parent Indian MNE is more likely to be relatively knowledge deficient than their more competent overseas subsidiaries. In this context, RKT plays an important role in transforming the location-bound assets in the host countries to create competitive advantage for the entire EMNE network (D'Agostino and Santangelo, 2012). This is also relevant considering the fact that EMNEs are latecomers in 
the international scene when compared to the DMNEs. This means they do not have the time to 'reinvent the wheel' when it comes to the state-of-the-art technologies and other competencies, if they have to compete effectively with their rather advanced global competitors. Hence they resort to acquiring advanced strategic assets via overseas acquisitions to leapfrog and overcome their inherent weaknesses and limitations (Luo and Tung, 2007; Mathews, 2006).

The attention to knowledge related attributes have been sparse in the extant RKT literature with the exception of the effect of knowledge relevance which was found to be more prominent for RKT than for conventional transfer (Yang, Mudambi and Meyer, 2008). Studies on RKT have been largely aimed at examining firm level aspects like absorptive capacity (Ambos, Ambos and Schlegelmilch, 2006), subsidiary roles and mandates (Ambos, Ambos and Schlegelmilch, 2006; Yang, Mudambi and Meyer, 2008), innovativeness (Hakanson and Nobel, 2001; Mudambi, Piscitello and Rabbiosi, 2014) and integrative and socialisation mechanisms (Hakanson and Nobel, 2001; Najafi-Tavani, Giroud and Sinkovics, 2012; Rabbiosi and Santangelo, 2013; Rabbiosi, 2011). Since this study focusses on parent EMNEs seeking strategic assets, we aim to look at the effects of tacitness which has been widely known for its strategic potential. Since tacit knowledge is most effectively shared through personal interactions via collaborations, this study also looks at the effects of organisational collaboration on RKT. RKT in the context of this study could be defined as the knowledge and skills that flow from the overseas subsidiaries to their parent units at home (Ambos, Ambos and Schlegelmilch, 2006; Gupta and Govindarajan, 2000).

\section{Knowledge-Based View}

Valuable knowledge has long been considered to be a strategic resource for firms, playing a vital role in sustaining their competitive advantage (Winter, 1987). The reason why "firms" 
are preferred to "markets" is often attributed to the fact that firms are more efficient than markets in handling KT (especially tacit) and knowledge integration (Almeida, Song and Grant, 2002; Kogut and Zander, 1993). Foreign direct investment (FDI) has always been regarded as a vehicle that facilitates such KT in firms (Spender and Grant, 1996). All of this focus on knowledge has paved the way for the knowledge-based view of the firm (Grant, 1996a), which has emerged mainly from the resource-based view of the firm (Barney, 1991). The latter focusses on the effective and efficient utilisation of the firm's idiosyncratic resources and capabilities, while the former focusses on the most strategically important intangible resource for a firm, namely knowledge. This stream of research has espoused concepts and theories such as tacit knowledge (Polanyi, 1962), organisational routines (Nelson and Winter, 1982), organisational competency (Prahalad and Hamel, 1990), resource-based view (Barney, 1991), codified and tacit knowledge (Kogut and Zander, 1992) and organisational knowledge creation (Nonaka, 1994; Nonaka and Takeuchi, 1995).

$\mathrm{KBV}$ emphasises the role of a firm in acquiring, assimilating, creating and utilizing firmspecific knowledge (Grant, 1996a). The KBV perspective depicts the firm as a repository of knowledge and competencies. The ability of the firm to exploit knowledge towards value creation depends on the strategic potential of this knowledge. The strategic potential of this knowledge is based on its value, rarity, inimitability and non-substitutability, which in turn will make it difficult for competitors to imitate (Barney, 1991), thus providing competitive advantage. Tacit knowledge (defined below) scores high on these characteristics and hence has a high potential in conferring competitive advantage on the firm possessing such knowledge. However, the problem with such knowledge is the fact that while it prevents competitors from replicating, it also hinders the transferability and exploitation of this knowledge within the firm (Spender and Grant, 1996). Hence KBV focusses on issues around transferability of knowledge and coordination within the firm. This issue of transferability 
'within the firm' is considered even more important than 'between firms' (Grant, 1996a). At the core of the issues around transferability is the concept of tacitness, which potentially makes the transfer more difficult, time consuming and costly (Kogut and Zander, 1992).

The basic distinction between tacit and explicit knowledge is that the former is difficult to articulate when compared to the latter (Polanyi, 1962). However, it also needs to be noted that explicit knowledge is always grounded in tacit knowledge and one needs to have tacit knowledge to understand explicit knowledge. Tacit knowledge is often embodied in individuals and organisational practices (Nelson and Winter, 1982) and more specifically in action, procedures, routines, commitments, ideals, values and emotions (Nonaka, Umemoto and Senoo, 1996). It is not easily codifiable and teachable (Kogut and Zander, 1992). Tacit knowledge is more "tied to the senses, tactile experience, movement skills, physical experiences, intuition, unarticulated mental models or implicit rules of the thumb" (Nonaka and von Krogh, 2009, p.636). All of these make tacit knowledge extremely strategic and a source of competitive advantage for the firm as discussed earlier.

Nonaka (1994) views tacit and explicit knowledge as mutually complementary (not separate) that exist along a continuum. The interaction between these two forms of knowledge (leading to conversions from one form to another) is used to explain the process of knowledge creation (Nonaka and Takeuchi, 1995). Regarding the acquisition of this tacit knowledge, it is best acquired through observation, action, practice and reflection (Nonaka and von Krogh, 2009) since it is not accessible through consciousness, but is more automatic, non-directed and often non-intentional (Reber, 1993). Hence tacit knowledge is communicated most effectively when there is a shared understanding between the entities involved in the transfer (Grant, 1996a). KBV also emphasises the presence of shared mental models and common experiences that could facilitate the transferability of this knowledge. All of these demand a 
collaborative environment that could trigger more personal interactions in order to facilitate the transfer of tacit knowledge.

\section{Social Capital Perspective}

In order to effectively transfer knowledge, and more specifically while dealing with tacit knowledge, collaborations between organisational units are vital. Joint activities involving individuals or teams from different organisational units create a shared understanding of each other's capabilities (Frost and Zhou, 2005) and an understanding of 'who knows what'. The social capital perspective (Nahaphiet and Ghoshal, 1998; Tsai and Ghoshal, 1998) emphasises the importance of such activities in creating a shared identity and common goals, thus aiding knowledge exchanges and further integration of this knowledge (Lee and Choi, 2003). The cognitive dimension of social capital focus especially on the role of shared vision and goals between organisational units ( $\mathrm{Li}$, Barner-Rasmussen and Björkman, 2007). The shared values and understanding between the organisational units are brought about by resource exchanges, joint participation in projects, working on resolving common issues that strengthen the emotional ties between the organisational units which in turn could potentially facilitate knowledge transfers. These cognitive elements act as the 'glue' that holds together geographically scattered organisational units (Persson, 2006).

Further, tacit knowledge is transferred effectively by observing, interacting and jointly engaging in the actual "doing" (Nonaka and Takeuchi, 1995; Park, Vertinsky and Becerra, 2015). This would also mean that MNEs have to rely more on inter-organisational collaboration while dealing with tacit KT in order to utilise this knowledge more effectively and efficiently. Hence the interplay between tacitness, inter-organisational collaboration and RKT needs to be explored further.

\section{Dimensions of RKT}


The initial studies on KT focussed on the extent of the transfer assuming that all knowledge transferred is likely to be beneficial to the target unit (Ambos, Ambos and Schlegelmilch, 2006; Bjorkman, Barner-Rasmussen and Li, 2004; Gupta and Govindarajan, 2000; Lyles and Salk, 1996; Minbaeva et al., 2003; Schulz, 2001). These studies thus operationalized KT in terms of the level or stocks of the flows of knowledge (viz. extent of $K T$ ) as provided by the source unit to the recipient unit. In other words, the KT that was studied here indicated the quantity of the flow rather than the actual value of this transfer to the parent. Other studies (Ambos and Ambos, 2009; Bjorkman, Fey and Park, 2007; Monteiro, Arvidsson and Birkinshaw, 2008; Perez-Nordtvedt et al., 2008; Tran, Mahnke and Ambos, 2010) questioned this approach by focussing on other dimensions of KT, which could be more meaningful. One of such dimensions of KT that has been examined is the actual benefits from KT (Ambos and Ambos, 2009; Bjorkman, Fey and Park, 2007). The emphasis here is on the impact of KT in that the transfer occurs only when the knowledge from the source unit actually influences the recipient unit. This line of inquiry shifted the emphasis from the extent KT to the benefits that the recipient unit has derived from the incoming knowledge. However, it also becomes pertinent to understand how these two dimensions, extent of transfer and benefits of transfer, are linked to each other. To date, the association between the extent of RKT and the benefits from RKT has not been examined. This is important given the high costs associated with RKT.

One of the main roles of the firm according to KBV is to put the incoming new knowledge to good use by integrating it with existing knowledge to enhance performance (Grant, 1996a; Nonaka and von Krogh, 2009). Effective knowledge utilization tends to occur when new knowledge fits with and builds on existing knowledge. This occurs more effectively when there is common knowledge that is shared between the two units (Yli-Renko, Autio and Tontti, 2002). This common knowledge is essential for efficient integration of knowledge 
(Grant, 1996b) since it enables the establishment of innate connections of existing knowledge with new knowledge. The similarity in vocabulary, conceptual knowledge and exposure to similar experiences (Grant, 1996b) all contribute to this common knowledge. The incoming knowledge by way of RKT provides the parent units with opportunities to be more familiar with the subsidiary unit's vocabulary, conceptual knowledge and experiences, which helps in building this much needed common knowledge. The more the build-up of this common knowledge by way of more incoming RKT (extent of RKT), the more likely that the parent unit can utilise the transferred knowledge effectively. Further, with more incoming RKT, there is better communication and shared understanding between the units which facilitates the development of stronger intra-organisational social capital (Yli-Renko, Autio and Tontti, 2002), which in turn enables the parent units to make more sense of this incoming knowledge, assess them and purposively select knowledge that is potentially more useful for them. Hence we propose;

H1: The greater the extent of RKT, the higher is the benefits from RKT.

\section{Tacitness and the two dimensions of RKT}

Knowledge is categorised on to two dimension; tacit (knowing how) and explicit (knowing what) knowledge (Polanyi, 1966). These dimensions of knowledge are not dichotomous, but are mutually dependent (Alavi and Leidner, 2001). Tacit knowledge is often referred to as the glue that holds together explicit knowledge (Dhanaraj et al., 2004), making it very vital for firms to sustain their competitive advantage. Tacitness could be attributed to a large extent to the codifiability (degree to which it can be encoded) and teachability (easy to train) of knowledge (Kogut and Zander, 1993). Tacit knowledge is very difficult to articulate and not very easy to teach others, which is one of the reasons that it is hard to imitate such knowledge (Nonaka and Von Korigh, 2009). These aspects of tacit knowledge contribute to knowledge 
ambiguity (Simonin, 1999), stickiness (Szulanski, 1996; von Hippel, 1994), inimitability (Foss, Knudsen and Montgomery, 1995) and inertness (Kogut and Zander, 1992). For these reasons, tacitness is also found to hinder KT (Simonin, 1999; Simonin, 2004; Zander and Kogut, 1995). The contexts of the source and recipient units of knowledge are likely to be different in this study, both culturally and geographically, which makes the transfer of tacit knowledge even more challenging. Hence the tacitness of the subsidiary knowledge may make it more difficult for the parent units to engage in RKT and could potentially dissuade them because of these inherent problems. Hence the following hypothesis;

$H 2 a$ : The more tacit the target subsidiary knowledge, the less will be the extent of RKT.

Because of its inherent value and strategic importance, tacit knowledge is also very valuable for EMNEs, which could aid their rapid catching up motives by spring-boarding to global success (Luo and Tung, 2007; Demirbag and Yaprak, 2015) and accelerate their learning (Mathews, 2006). The tacit knowledge residing with the subsidiary unit is bound to be highly valuable and beneficial for the parent EMNE in building up the competencies and capabilities, which they lack. This is especially so as tacit knowledge is rarer and more inimitable than explicit knowledge thus lending the much needed competitive advantage for EMNEs. The fact that such knowledge is limited in prevalence also means that this knowledge has the potential to earn above-normal rents (Barney, 1991; Grant, 1996a). The tacit subsidiary knowledge could help the EMNE parent to bridge the knowledge gap that they often have in terms of cutting edge technology, management and marketing know-how. Hence we propose the following hypothesis;

$H 2 b$ : The more tacit the target subsidiary knowledge, the greater will be the benefits from RKT. 
Collaborations increases the level of openness and personal interaction amongst employees (Lee and Choi, 2003; Park, Vertinsky and Becerra, 2015), which in turn reduces the tendency to withhold valuable information. Such an environment can also dismantle organizational barriers between individuals located in different organisational units, thereby facilitating the exchange of ideas and information amongst employees. Collaborations also help in the development of shared cognitive models (Grant, 1996a) which in turn help organisational units make more sense of the knowledge possessed by other units. These collaborations create strong ties between employees in different organisational units and aid the formation of shared understanding and common goals, which is vital for an efficient and effective KT and the associated learning (Frost and Zhou, 2005; McGuinness et al, 2013). Hence we put forward the following hypothesis;

$H 3 a$ : The extent of RKT is positively related to the collaboration between the involved units.

Organisational collaboration is also a pre-requisite to the process of integrating the incoming knowledge with existing knowledge to create new knowledge (Lee and Choi, 2003). Benefits can be derived from the transferred knowledge when there is efficient integration (Grant, 1996) and application of this knowledge by the recipient organisational unit. For this knowledge integration to materialise, collective sense-making and shared understanding is again very vital (Newell, Tansley and Huang, 2004). Thus collaboration assists in extracting better value from the knowledge transferred, because of this shared understanding and collaborative synergy. Hence the following hypothesis;

$H 3 b$ : The benefits from RKT is positively related to the collaboration between the involved units. 
As discussed earlier, EMNE units face great difficulties in the transfer of tacit knowledge owing to its highly contextual and embedded nature. Given that the parent units and their subsidiary units are geographically scattered, it becomes vital for these units to engage in inter-organisational collaboration, in order to be able to exchange information and views more effectively. Hence it is essential to create more potential avenues and opportunities for parent and subsidiary units to gainfully interact with one another. The reliance on such collaborative mechanisms would be greater if the target subsidiary knowledge is more tacit in nature. Since this tacit knowledge is strategic in nature and is much sought after by the parent units, it is more likely that the parent EMNE will focus more on developing shared understanding and goals, which could be fostered through inter-organisational collaborations. Hence the hypothesis;

H4: The parent units rely more on inter-organisational collaboration when the target subsidiary knowledge is more tacit in nature.

As shown in Figure 1, relationships between dimensions of tacitness, collaboration, the extent of RKT and benefits from RKT in emerging market MNE subsidiaries are delineated in a path model in which a series of control variables are also taken into account.

\section{Figure 1: PLS Path Model}

\section{Research Methodology}

\section{Sample and Data Collection}


The data for this study was collected using a questionnaire that was administered to the managers of 329 Indian firms, who had engaged in overseas acquisitions between 2000 and 2010. The list of 329 MNEs were mainly compiled from two reports published by Federation of Indian Chambers of Commerce and Industry (FICCI, 2006; FICCI and Grant Thornton, 2010) and supplemented by other press releases and reports. The MNEs with acquisitions during the period 2000 to 2010 were selected because of the fact that there was a surge in the number of overseas M\&As by Indian MNEs since 2003 (Nayyar, 2008), which is also indicated by the rise in Outward Foreign Direct Investment during this period. Further, Indian MNEs have shown a preference for more committed entry modes (mainly majority-owned acquisitions) and developed countries in terms of location choices (Nair and Demirbag, 2015; Pradhan, 2007; Sethi, 2009). The learning from such acquisitions has also been discussed extensively in the literature (Buckley, Fosans and Munjal, 2012; Buckley et al., 2016b; Chittoor and Ray, 2007; Elango and Pattnaik, 2007). Indian MNEs have thus left an impressive footprint when it comes to their overseas acquisitions in the last decade and most of them in the developed markets, indicating their focus on knowledge seeking pursuits.

The data collection phase ran for 6 months following which 114 responses were received, out of which 101 were found to be useful, while the others had large amount of missing or invalid data. This provided a firm level response rate of $31 \%$. Services of research firms based in India were utilised to identify potential respondent managers and establish contacts to administer the surveys. The respondent managers were mainly senior managers $(71 \%)$ in these MNEs, which included CEOs, COOs, CIOs, VPs, GMs and Business Heads. Middle level managers who responded to the survey $(29 \%)$ included department or function heads. Extant literature (Bjorkman, Barner-Rasmussen and Li, 2004; Gupta and Govindarajan, 2000; Simonin, 2004) indicates that studies on KT have had heads of organisations or specific 
functions as respondents, since they have a better overview about overseas operations of subsidiaries, interactions and transactions with these subsidiaries and other post-integration activities. These respondent managers had an average tenure of 9 years in their respective organisations. The study further focusses on the recipient parent unit's perspective (Ambos $e t$ al. 2006; Rabbiosi 2011), since they are best equipped to assess the extent of knowledge they have actually received at their end and the benefits that such transfers have yielded (nodal study). The respondent MNE's mean age is 37 years and were mainly from Pharmaceutical \& Biotech (20\%), IT \& ITeS (17\%), Automotive (12\%), Chemicals \& Fertilizers (11\%) and Metals \& Mining (11\%). The focal overseas subsidiaries were mainly from USA (32\%), UK (19\%), Germany (9\%), Canada (3\%), Australia (2\%), France (2\%) and rest of Europe (18\%). Thus $92 \%$ of the subsidiaries were from developed countries.

\section{Non-response and Common Method Bias}

To assess non-response bias, t-tests (independent sample) were conducted to check if the respondent firms were any different from the non-respondent firms with respect to the main firm level attributes such as age, revenue, and profit-loss (Ambos and Ambos, 2009). The tests indicated that there were not any significant differences (at $p \leq .05$ ). In order to reduce common method bias, procedural remedies were incorporated (Chang, Witteloostuijn and Eden, 2010; Podsakoff et al., 2003). This includes ensuring anonymity to all the respondents in the study so that they could provide honest responses, thereby reducing chances of social desirability bias. There was also a good mix of different response formats (Podsakoff et al., 2003) in the questionnaire including open ended, fixed alternative and Likert scale questions. The questionnaire was also provided with two sections, one requesting data on the parent unit and the other on the focal subsidiary unit. The ordering of questions across these two sections was done to ensure that potential linkages between the predictor and criterion variables were 
not explicitly revealed. Post-hoc analysis using Harmans one-factor test was conducted, including all the reflective variables from the questionnaire. It showed that no single factor emerged that accounts for most of the variance (Williams, 2009).

\section{Measures}

As discussed earlier, this was a nodal study to capture RKT from the recipient EMNE parent unit's perspective. The scales to measure the constructs of this study have been adapted from the existing literature and uses 7-point Likert scales ( $1=$ Strongly Disagree to $7=$ Strongly Agree). The respondents were asked to choose a focal subsidiary that they were most familiar with, to provide their responses. Based on prior studies (Ambos, Ambos and Schlegelmilch, 2006; Gupta and Govindarajan, 2000), the different knowledge types to be considered for the transfer were identified as technological know-how, marketing know-how and management know-how. Technological knowledge plays a crucial role especially in manufacturing, knowledge intensive and high-tech industries (Almeida, Song and Grant, 2002) and hence many scholars have explored transfers with this type of knowledge (Simonin, 2004; Zander and Kogut, 1995; Hakanson and Nobel, 2000). Similarly, the transfer of marketing knowledge has also been the focus of several other studies (Monteiro, Arvidsson and Birkinshaw, 2008; Simonin and Ozsomer, 2009). In addition to technological knowledge and marketing knowledge, organisational knowledge encompasses management knowledge (Fey and Furu, 2008; Zhao and Anand, 2009) that deals mainly with management and competitive strategies and relevant business models.

The extent of RKT was measured using a three item scale (Gupta and Govindarajan, 2000), where the respondents were asked to rate the extent to which "the focal subsidiary provides them with knowledge and skills related to technological know-how". This question was then repeated for the other two knowledge types (ERKT_tech, ERKT_marketing and 
ERKT_mgmnt as referred to in Table 2) to form a three item scale. Organisational collaboration was measured using a four item scale (Richey and Autry, 2009) which had the following questions i) Both Parent and Subsidiary work together to share new ideas (Collab1) ii) Both Parent and Subsidiary frequently share proprietary information with one another (Collab2) iii) Both Parent and Subsidiary work together to take advantage of new opportunities (Collab3) iv) Both Parent and Subsidiary work together toward common goals (Collab4). Tacitness was measured using a four item scale (reverse coded), which was repeated for the three knowledge types (Monteiro, Arvidsson and Birkinshaw, 2008). The questions were i) A manual describing how your subsidiary's activities are executed could be documented (Tacit11, Tacit12 and Tacit13 for the three knowledge types) ii) New staff can easily learn how to perform the operations/services that your subsidiary offers by talking to skilled employees (Tacit21, Tacit22 and Tacit23) iii) Training new personnel in subsidiary's operations/services is typically a quick and easy job (Tacit31, Tacit32 and Tacit33) iv) New personnel with a university education can perform the operations/services that our subsidiary offers (Tacit41, Tacit42 and Tacit43). The benefits from RKT was measured using three item scale (Ambos, Ambos and Schlegelmilch, 2006), where the respondents were asked to rate the "benefits from the knowledge and skills provided by the subsidiary related to technological know-how", which was then repeated for the other two knowledge types (BRKT_tech, BRKT_marketing, BRKT_mgmnt as referred to in Table 2) to form a three item scale.

The study has controlled for the effects of country level and firm level variables. The main firm level controls are the relative size and age of the parent unit with respect to the subsidiary unit. Size and age are some of the main firm level variables that influence KT (Van Wijk, Jansen and Lyles, 2008). Acquisition age and organisational distance between the 
parent and the subsidiary unit have also been controlled for in this study, based on prior studies (Simonin, 1999; Yang, Mudambi and Meyer, 2008). The logarithmic transformation of age, size and acquisition age has been performed to address the skewness associated with this kind of data. Cultural differences between source and recipient units are also likely to inhibit KT (Ambos, Ambos and Schlegelmilch, 2006), and hence the cultural distance was also controlled for. Using the approach by Kogut and Singh (1988), the four cultural dimensions (Hofstede, 1980) were used to measure cultural distance.

\section{Analysis and Results}

The correlations between the various constructs used in the study along with the mean and standard deviation (from SPSS) have been presented in Table 1. Structural Equation Modelling using Partial Least Squares (PLS) has been employed in this study using SmartPLS V3.0 (Ringle, Wende and Becker, 2015). This is a soft modelling technique and is variance based, with many advantages (Cool, Dierickx and Jemison, 1989; Hair et al., 2012; Johansson and Yip, 1994; Ringle, Sarstedt and Straub, 2012) that include i) flexibility with respect to the assumptions on multivariate normality ii) usage of both reflective and formative indicators iii) ability to analyse complex models using smaller samples iv) potential use as a predictive tool for theory building. The analysis will be performed in two stages, the first being the assessment of reliability and validity of the measurement model and the second the assessment of the structural model (Hulland, 1999). This study uses PLS since it involves a relatively smaller sample to analyse multiple paths that can be estimated simultaneously for the model as a whole.

\section{Table 1}




\section{Measurement Model}

The measurement model for this study has only reflective indicators and hence the reliability and the validity of all the latent constructs will be assessed. Table 2 provides the latent constructs assessed along with the loading of the indicators (or manifest variables) on the respective constructs, average variance (AVE), composite reliability (CR) and Cronbachs alpha $(\alpha)$. The indicators should load the highest on their respective constructs when compared to the other constructs (Chin, 1998), and the loading on the constructs should be > 0.55 ; these criteria are satisfied and the loadings are all significant $(\mathrm{p} \leq .001)$. This indicates the reliability of the indicators. Convergent validity and composite reliability of the scales are assessed using several criteria including Cronbach's $\alpha \geq 0.7$ (Nunnally, 1978), CR $\geq 0.7$ (Bagozzi and Yi, 1988) and AVE $\geq 0.5$ (Bagozzi and Yi, 1988). These conditions have been satisfied for all the latent constructs in this study as illustrated in Table 2. Fornell-Larcker criterion (Fornell and Larcker, 1981) was used to assess discriminant validity. The heterotrait-monotrait ratio (HTMT) of correlations was also assessed for testing discriminant validity. The HTMT ratio of correlations were below 0.90 for all the reflective constructs used in the study (Henseler, Ringle and Sarstedt, 2015). This was done by comparing construct's correlation with other constructs (correlation) and the construct's correlation with its own indicators (square root of AVE), with the former being less than the latter. This established discriminant validity for the latent constructs in this study.

\section{Table 2}

\section{Structural Model}


The assessment of structural models in PLS is based on the $\mathrm{R}^{2}$ estimates, path coefficients and their t-statistics. The predictive power of the model is estimated using $\mathrm{R}^{2}$ with values of .67, 0.33 and 0.19 indicating substantial, moderate and weak PLS models (Chin, 1998) respectively. The strength of the relationship between the predictor and criterion variables is assessed using the path coefficients and the significance of the same is provided by the tstatistics. PLS requires a bootstrapping procedure to generate t-statistics (with sample = 2000) which in turn is used for hypotheses testing (Chin, 1998). The model is depicted in Figure 1 and Table 3 provides the $\mathrm{R}^{2}$ estimates, the corresponding path coefficients and their significance, for the hypothesised relationships in this study. The $\mathrm{R}^{2}$ values indicate that model has adequate predictive power, which also indicates that the antecedents together explain for most of the variance in the dependent variables. The VIF (Variance Inflation Factor) values were also checked for the presence of multi-collinearity and the values $(<10)$ suggest that this is not a potential issue.

\section{Table 3}

The model analyses the effects of the identified determinants on the extent of RKT and the benefits from RKT. The effect of tacitness was significant in both the models. However, a negative relationship was hypothesised in $\mathrm{H} 2 \mathrm{a}$ between tacitness of the target subsidiary knowledge and extent of RKT as against the observed positive relationship (H2a, $\beta=.714$ at $\mathrm{p} \leq .001)$. Hence there was no support for hypothesis H2a. The positive effect of tacitness on the benefits from RKT was significant confirming the hypothesis $(\mathrm{H} 2 \mathrm{~b}, \beta=.698$ at $\mathrm{p} \leq .001)$. The positive effects of collaboration have been established on both dimensions of RKT. The effect of collaboration on the extent of RKT $(\mathrm{H} 3 \mathrm{a}, \beta=.165$ at $\mathrm{p} \leq .1)$ and the benefits from 
RKT $(\mathrm{H} 3 \mathrm{~b}, \beta=.163$ at $\mathrm{p} \leq .05)$ were significant. In addition, the positive effects of tacitness on collaboration $(\mathrm{H} 4, \beta=.575$ at $\mathrm{p} \leq .001)$ and the extent of RKT on benefits from RKT $(\mathrm{H} 1$, $\beta=.357$ at $\mathrm{p} \leq .001$ ) have also been confirmed.

\section{Discussion and Conclusions}

This study examined the link between two key dimensions of RKT, namely the extent of RKT and the benefits that parent units derive from the RKT. The study also focused on an important strategic dimension of knowledge for the firm viz. tacitness and the level of organisational collaboration that enable sharing of tacit knowledge in a joint model involving both the dimensions of RKT.

Tacitness of knowledge is associated with difficulty to transfer (Simonin, 1999, 2004; Szulanski, 1996), while the value of tacit knowledge is widely recognised as vital to the competitive advantage of firms (Grant, 1996a). Firms have to balance the high costs involved in the transfer of tacit knowledge with the expected unique and valuable benefits that they derive from it. The results from this study indicate, surprisingly, that the extent of RKT increases with the tacitness of the subsidiary knowledge. This indicates that EMNEs have engaged more with RKT when they encountered tacit knowledge, since it is more difficult to materialise such transfer. This is perhaps because of its high importance to their springboarding (Luo and Tung, 2007) and ongoing learning (Mathews, 2006). This underscores their commitment and their intent towards acquiring strategic knowledge assets, which is facilitated by cross-border M\&As. This is understandable because tacit knowledge, which is closely linked to the experiences of their overseas subsidiaries, is essential to attain the much needed competitive edge in global markets, which EMNEs lack as latecomers. Further, as expected, the study reveals that tacitness of the subsidiary knowledge has a positive influence on the benefits arising from RKT. The finding that tacit knowledge yields 
more benefits for the EMNEs is in accordance with the KBV of the firm (Grant, 1996a). Indeed, one of the advantages of acquisitions is the relative ease in absorbing tacit knowledge relative to arm's length relationships such as strategic alliances.

The positive relationship between the extent of RKT and benefits from RKT is another key finding from this study. Prior studies have highlighted the fact that knowledge transferred may not always benefit the recipient unit (Ambos, Ambos and Schlegelmilch, 2006). However, the advantages emerging from cross-border KT cannot be overlooked. Gaining knowledge through KT and the associated learning has been cited as the top three reasons for overseas acquisitions (Kale, 2009), which suggests the potential benefits from these transfers. In the case of EMNEs, studies suggest that they use this learning to catch-up and compete more effectively with their global counterparts (Lou and Tung, 2007). In the context of this study, the results indicate that EMNEs have been able to yield more benefits with greater extent of RKT. Further research using case studies and in depth interviews could provide much needed insights into why EMNEs' benefits more with greater extent of RKT. Organisational mechanisms or other firm level factors that could potentially mediate or moderate this relationship could also be identified from such studies.

Collaboration between organisational units involved in a transfer has been found to have significant positive influence on both the benefits from RKT and the extent of RKT. The social capital perspective (Nahaphiet and Ghoshal, 1998; Tsai and Ghoshal, 1998), of which collaboration is an important constituent element, stresses on the creation of shared meanings and interpretations, and having common goals and shared identities, which are all conducive to knowledge exchanges. For EMNEs, it is vital that they have organisational mechanisms that foster personal interactions in order to create a collaborative environment, especially in view of the cultural and organisational differences between the parent emerging market units 
and their overseas subsidiary units. Further, when it comes to the transfer of tacit knowledge, such personal interactions are most effective (Nonaka and Takeuchi, 1995). This has also been empirically established by the results from this study, which indicate that EMNEs rely more on collaborative efforts when dealing with tacit knowledge. Such collaborative efforts enable the EMNEs to better integrate this incoming knowledge with their existing knowledge to be able to create more value for themselves. This finding is thus in accordance with the social capital perspective which postulates that collaborations create shared identity, common goals and understanding between units, which is vital for sharing tacit knowledge. Hence the need to rely more on collaborative engagements to transfer such tacit knowledge, which in turn could also help EMNEs better realise benefits from the same. Again, future in-depth case studies could further uncover the mechanisms through which tacit knowledge is absorbed and integrated within EMNEs.

The study has several implications for scholars and practitioners. Theoretically, the extant view discusses the difficulty in transferring knowledge that is tacit in nature, which may impede firms from engaging with these transfers. It is true that it could hamper conventional KT where the main aim could be to engage the subsidiary in lower-end and labour-intensive operations. In such cases, the parent could prefer to transfer knowledge that can be easily codified and taught, and hence may deter from transferring tacit knowledge. However, in EMNE parent units engaging in RKT, the main purpose is to tap into years of subsidiary experience and expertise. Consequently, tacitness of the associated subsidiary knowledge may not be perceived as a deterrent (although difficult, indicating they had to engage with more RKT to materialise such transfers), because of its strategic value in their attempts to springboard their way to global success. This study thus highlights the importance of the knowledge context and awareness of knowledge attributes with regards to examining RKT, which has only received scant attention in the extant literature. 
The emerging market parent units have found this tacit knowledge residing with their overseas subsidiaries to be beneficial as well. Hence this study also provides empirical support for the much discussed knowledge seeking phenomenon of EMNEs, which is focussed on the accelerated learning from their overseas subsidiaries. Unique to this study is also a joint model that examines both the dimensions of RKT. The study shows that the more the emerging market parent units engage in RKT, the more benefits they accrue, which further throws light on the effectiveness of such transfers. This is particularly relevant since there could be situations when considerable levels of knowledge are transferred but the recipient unit is unable to reap any benefits from them. However, in the case of EMNEs, it shows that their attempts to learn cumulatively from these transfers have been worthwhile. Thus this study extends our current understanding of RKT. The study did not find any differential effects with respect to the two dimensions. However, it also needs to be noted that when dealing with knowledge attributes and other organisational mechanisms, their influence could be different on the various dimensions. For example, it is possible that certain antecedents could have a greater impact on the speed of the transfer, while others could influence the frequency of transfer more. This makes it pertinent to have more studies that explore other multiple dimensions of KT based on the antecedents that are being analysed. This study also sheds further light into the role of RKT in bridging the asymmetries between different countries with varying levels of technological development, skills and competencies.

The results from the study can inform managerial practices in terms of designing appropriate organisational mechanisms that could potentially lead to knowledge transfers that are more beneficial and effective. Managers responsible for KT need to be more aware of the nature of the knowledge involved with the transfer and design their organisational mechanisms accordingly. They need to understand that the knowledge embedded in the experience of their 
competent overseas subsidiaries could be vital to the development of superior skills and competencies that are extremely valuable for the entire MNE network. For MNEs, with subsidiaries dispersed globally, tapping into this kind of knowledge could prove to be extremely beneficial to other units within the MNE network since they could be transformed into competitive capabilities and other positive outcomes like improved efficiency, productivity and performance. Managers, especially from EMNEs, could focus more on cross-border collaborative projects that could enable them to tap into the very valuable expertise of their advanced subsidiaries, which in turn could help them realise their global ambitions. This is possible by designing more joint projects across borders, task committees and knowledge sharing forums involving their different organisational units, especially targeting their more competent subsidiaries. Such collaborations could also help organisational units look beyond their cultural and institutional differences towards developing common goals, mutual trust and shared understanding, which is even more pertinent when it comes to sharing tacit knowledge. This further strengthens relationships between the units leading to more knowledge transfers which in turn leads to cumulative learning, preparing the units even better to utilise more of such incoming knowledge.

Drawing from the KBV and the social capital perspective, this study reveals the links between the two different dimensions of RKT and explores the effects of tacitness of target subsidiary knowledge and collaboration on these dimensions. One of the limitations of this study is that it has a cross-sectional design and hence would be unable to clearly establish the causalities. The study is also nodal, which accounts for the parent perspective as the beneficial recipient unit. A dyadic perspective, which includes the subsidiary perspective could lend more meaningful insights into the process of RKT. It also needs to be noted that KT could be intentional or unintentional (Mudambi, 2002) and is sometimes invisible to managers because it could also materialise informally via employee networks (Whelan et al., 
2011). These informal networks could serve as alternative pathways to KT, with knowledge brokers and their networks playing an important role in such transfers (Tsai and Ghoshal, 1998; Whelan et al., 2011). Hence further studies that explore the mechanics of such networks and alternative pathways to KT can enhance our understanding of how recipient units derive benefits from such transfers. The study has been conducted in India, one of the emerging markets and hence generalising the findings to other emerging markets has to be done cautiously because of the heterogeneous nature of such markets. More studies in other emerging markets could also provide better insights into the dynamics of RKT in terms of contextual effects. 


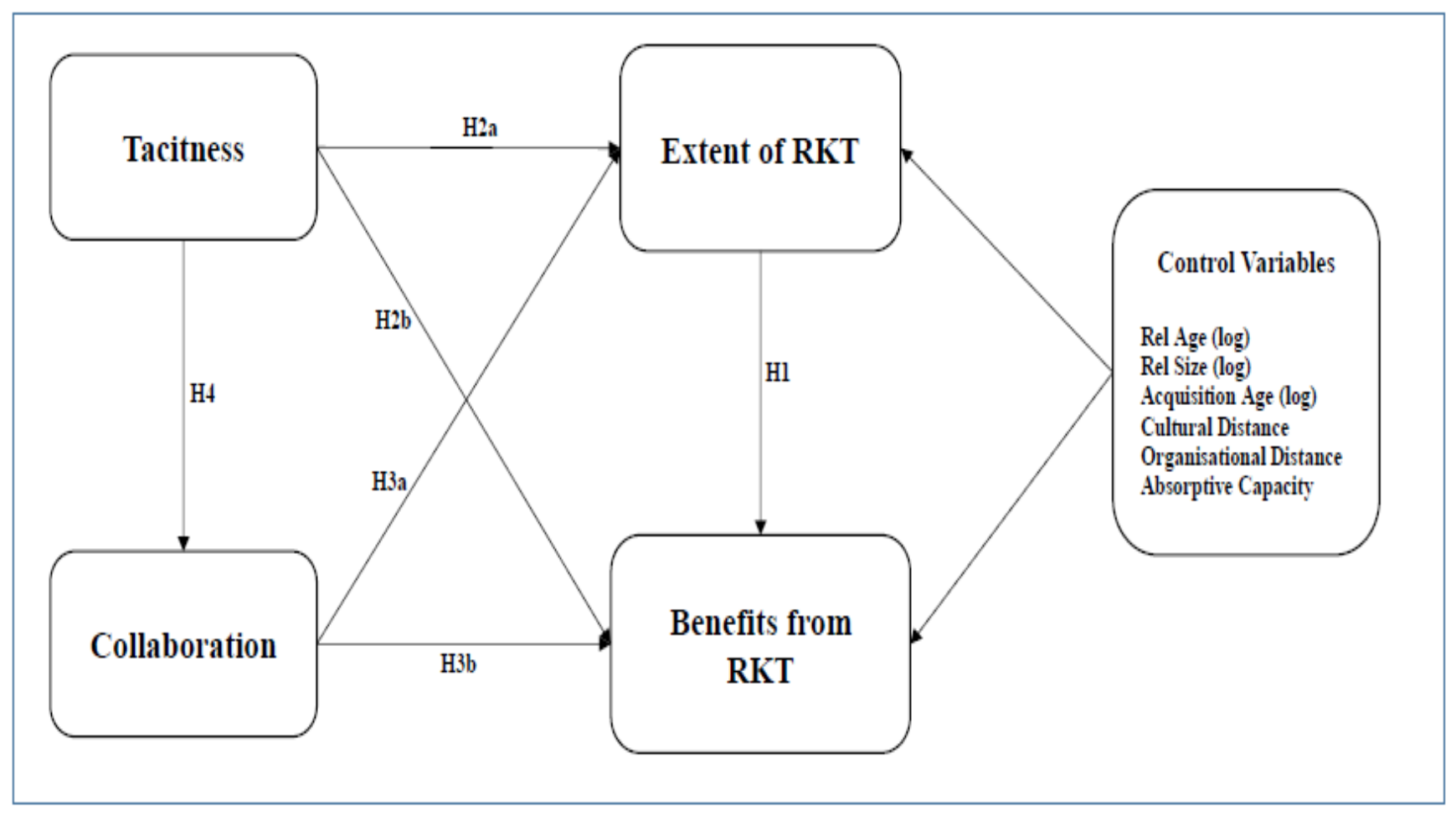

Figure 2: PLS Path Model 
Table 1: Correlation Table

\begin{tabular}{|c|c|c|c|c|c|c|c|c|c|c|c|}
\hline & Mean & SD & 1 & 2 & 3 & 4 & 5 & 6 & 7 & 8 & 9 \\
\hline Extent of RKT & 4.81 & 1.29 & 1 & & & & & & & & \\
\hline Collaboration & 5.88 & 0.99 & $.51^{* *}$ & 1 & & & & & & & \\
\hline Tacitness & 4.99 & 1.12 & $.72^{* *}$ & $.57^{* *}$ & & & & & & & \\
\hline Benefits RKT & 4.97 & 1.29 & $.74^{* *}$ & $.55^{* *}$ & $.76^{* *}$ & 1 & & & & & \\
\hline Org. distance & 4.69 & 1.40 & $.33^{* *}$ & $.41^{* *}$ & $.43^{* *}$ & $.43^{* *}$ & 1 & & & & \\
\hline Cult. distance & 1.49 & 0.53 & $-.22^{*}$ & .01 & -.06 & -.14 & $-.20^{*}$ & 1 & & & \\
\hline Acquis. age & 4.51 & 2.60 & -.12 & .03 & -.05 & -.16 & .07 & .11 & 1 & & \\
\hline Rel. Age & 3.78 & 6.22 & .20 & .02 & .10 & .19 & .04 & $-.24^{*}$ & -.19 & 1 & \\
\hline Rel. Size & 47.79 & 125.21 & .12 & .03 & -.01 & .01 & .16 & -.19 & -.03 & .13 & 1 \\
\hline
\end{tabular}


Table 2: Reliability and Validity of the Measurement Model

\begin{tabular}{|c|c|c|c|c|c|}
\hline Constructs & Items & $\begin{array}{c}\text { Outer } \\
\text { Loading }\end{array}$ & AVE & $\mathbf{C R}$ & $\begin{array}{c}\text { Cronbach's } \\
\alpha\end{array}$ \\
\hline Benefits of RKT & $\begin{array}{l}\text { BRKT_tech } \\
\text { BRKT_marketing } \\
\text { BRKT_mgmnt }\end{array}$ & $\begin{array}{l}0.772 \\
0.908 \\
0.877\end{array}$ & .730 & .890 & .813 \\
\hline Tacitness & $\begin{array}{l}\text { Tacit11 } \\
\text { Tacit12 } \\
\text { Tacit13 } \\
\text { Tacit21 } \\
\text { Tacit22 } \\
\text { Tacit23 } \\
\text { Tacit31 } \\
\text { Tacit32 } \\
\text { Tacit33 } \\
\text { Tacit41 } \\
\text { Tacit42 } \\
\text { Tacit43 }\end{array}$ & $\begin{array}{l}0.703 \\
0.742 \\
0.781 \\
0.745 \\
0.802 \\
0.855 \\
0.729 \\
0.740 \\
0.850 \\
0.759 \\
0.802 \\
0.807\end{array}$ & .605 & .948 & .940 \\
\hline Collaboration & $\begin{array}{l}\text { Collab1 } \\
\text { Collab2 } \\
\text { Collab3 } \\
\text { Collab4 }\end{array}$ & $\begin{array}{l}0.882 \\
0.768 \\
0.907 \\
0.886\end{array}$ & .744 & .920 & .884 \\
\hline Extent of RKT & $\begin{array}{l}\text { ERKT_tech } \\
\text { ERKT_marketing } \\
\text { ERKT_mgmnt }\end{array}$ & $\begin{array}{l}0.789 \\
0.879 \\
0.889 \\
\end{array}$ & .728 & .889 & .812 \\
\hline
\end{tabular}

All outer loadings are significant at $p<.001$ 
Table 3: PLS Path Coefficients (Total)

On the Extent of

On the Benefits RKT from RKT

\section{$\underline{\text { Control Variables }}$}

Relative Size (log)

.087

.072

Relative Age (log)

$-.095$

$-.133^{*}$

$-.047$

$-.049$

$-.165^{*}$

Cultural Distance

$-.048$

Organisational Distance

Independent Variables

Extent of RKT

Tacitness

Collaboration

$\begin{array}{ll}H 2 a & .714^{* *} \\ H 3 a & .165^{*}\end{array}$

H1

$.357^{* * * *}$

$.165^{*}$

$\mathrm{H} 2 \mathrm{~b}$

$.698^{* * * *}$

Tacitness $\rightarrow$ Collaboration

H3b

$.163^{* *}$

$\mathbf{R}^{2}$

Adjusted R $\mathbf{R}^{2}$ 


\section{References}

Alavi, M. and D. E. Leidner (2001). 'Review: Knowledge Management and Knowledge Management Systems: Conceptual Foundations and Research Issues', MIS Quarterly, 25, pp. 107-136.

Almeida, P., J. Song and R. M. Grant (2002). 'Are Firms Superior to Alliances and Markets? An Empirical Test of Cross-Border Knowledge Building', Organization Science, 13, pp. $147-161$.

Ambos, T. C. and B. Ambos (2009). 'The impact of distance on knowledge transfer effectiveness in multinational corporations', Journal of International Management, 15, pp. 114.

Ambos, T. C., B. Ambos and B. B. Schlegelmilch (2006). 'Learning From Foreign Subsidiaries: An Empirical Investigation of Headquarters' Benefits from Reverse Knowledge Transfers', International Business Review, 15, pp. 294-312.

Argote, L. and P. Ingram (2000). 'Knowledge Transfer: A Basis for Competitive Advantage in Firms', Organizational Behavior and Human Decision Processes, 82, pp. 150-169.

Awate, S., M. M. Larsen and R. Mudambi (2014). 'Accessing vs sourcing knowledge: A comparative study of R\&D internationalization between emerging and advanced economy firms', Journal of International Business Studies, 46, pp. 63-86.

Bagozzi, R. P. and Y. Yi (1988). 'On the evaluation of structural equation models', Journal of the Academy of Marketing Science, 16, pp. 74-94. 
Bangara, A., S. Freeman and W. Schroder (2012). 'Legitimacy and accelerated internationalisation: An Indian perspective', Journal of World Business, 47, pp. 623-634.

Barney, J. B. (1991). 'Firm resources and sustainable competitive advantage', Journal of Management, 17, pp. 99-120.

Björkman, I., C. F. Fey and H. J. Park (2007). 'Institutional theory and MNC subsidiary HRM practices: Evidence from a three-country study', Journal of International Business Studies, 38, pp. 430-446.

Björkman, I., W. Barner-Rasmussen and L. Li (2004). 'Managing Knowledge Transfer in MNCs: The Impact of Headquarters Control Mechanisms', Journal of International Business Studies, 35, pp. 443-455.

Buckley, P. J., N. Forsans and S. Munjal (2012). 'Host-home country linkages and hosthome country specific advantages as determinants of foreign acquisitions by Indian firms'. International Business Review, 21, pp. 878-890.

Buckley, P. J., S. Munjal, P. Enderwick and N. Forsans (2016a). 'Cross-border acquisitions by Indian multinationals: Asset exploitation or asset augmentation?', International Business Review, 25, pp. 986-996.

Buckley, P. J., S. Munjal, P. Enderwick and N. Forsans (2016b). 'The role of experiential and non-experiential knowledge in cross-border acquisitions: The case of Indian multinational enterprises'. Journal of World Business, 51, pp. 675-685. 
Chang, S.-J., A. V. Witteloostuijn and L. Eden (2010). 'From the Editors: Common Method Variance in International Business Research', Journal of International Business Studies, 41, pp. 178-184.

Chin, W. W. (1998). 'The partial least squares approach to structural equation modelling'. In G. A. Marcoulides (eds), Modern methods for business research, pp. 295-336. New Jersey: Lawrence Erlbaum Associates.

Chittoor, R. and S. Ray (2007). 'Internalization Paths of Indian Pharmaceutical firms - A strategic group analysis', Journal of International Management, 13, pp. 338-355.

Cool, K., I. Dierickx and D. Jemison (1989). 'Business Strategy, Market Structure and RiskReturn Relationships: A Structural Approach', Strategic Management Journal, 10, pp. 507522.

D'Agostino, L. M. and G. D. Santangelo (2012). 'Do Overseas R\&D Laboratories in Emerging Markets Contribute to Home Knowledge Creation? An Extension of the Double Diamond Model', Management International Review, 52, pp. 251-273.

Demirbag, M., and Yaprak, A.(Eds) (2015) Handbook of Emerging Market Multinational Corporations, Chelthenham.

Denrell, J., N. Arvidsson and U. Zander (2004). 'Managing knowledge in the dark: An empirical study of the reliability of capability evaluations', Management Science, 50, pp. 1491-1503. 
Dhanaraj, C., M. A. Lyles, H. K. Steensma and L. Tihanyi (2004). 'Managing Tacit and Explicit Knowledge Transfer in IJVs: The Role of Relational Embeddedness and the Impact on Performance', Journal of International Business Studies, 35, pp. 428-442.

Elango, B. and C. Pattnaik (2007). 'Building capabilities for international operations through networks: a study of Indian firms', Journal of International Business Studies, 38, pp. 541555.

Fey, C. F. and P. Furu (2008). 'Top management incentive compensation and knowledge sharing in multinational corporations', Strategic Management Journal, 29, pp. 1301-1323.

FICCI (2006). Study conducted on 306 foreign acquisitions by Indian firms from January 2000 to June 2006.

FICCI and Grant Thornton (2010). Investing in the European Union - lists the M\&A by Indian MNEs in the European Union during 2005 to 2010.

Fornell, C. and D. F. Larcker (1981). 'Evaluating Structural Equation Models with Unobserved Variables and Measurement Error', Journal of Marketing Research, 18, pp. 3950.

Foss, N. J., C. Knudsen and C. A. Montgomery (1995). 'An exploration of common ground: Integrating evolutionary and strategic theories of the firm'. In C. A. Montgomery (eds), Resource-Based and Evolutionary Theories of the Firm, pp. 1-17. London: Kluwer.

Frost, T. S. and C. Zhou (2005). 'R\&D Co-Practice and 'Reverse' Knowledge Integration in Multinational Firms', Journal of International Business Studies, 36, pp. 676-687. 
Giuliani, E., S. Gorgoni, C. Gunther and R. Rabellotti (2014). 'Emerging versus advanced country MNEs investing in Europe: A typology of subsidiary global-local connections', International Business Review, 23, pp. 680-691.

Grant, R. M. (1996a). 'Toward a Knowledge-Based Theory of the Firm', Strategic Management Journal, 17, pp. 109-122.

Grant, R. M. (1996b). 'Prospering in Dynamically-Competitive Environments: Organizational Capability as Knowledge Integration', Organization Science, 7, pp. 375-387.

Gupta, A. K. and V. Govindarajan (2000). 'Knowledge Flows within Multinational Corporations', Strategic Management Journal, 21, pp. 473-496.

Hair, J. F., M. Sarstedt, C. M. Ringle and J. A. Mena (2012). 'An assessment of the use of partial least squares structural equation modeling in marketing research', Journal of the Academy of Marketing Science, 40, pp. 414-433.

Hakanson, L. and R. Nobel (2000). 'Technology Characteristics and Reverse Technology Transfer', Management International Review, 40, pp. 29-48.

Hakanson, L. and R. Nobel (2001). 'Organizational Characteristics and Reverse Technology Transfer', Management International Review, 41, pp. 395-420.

Henseler, J., C. M. Ringle and M. Sarstedt (2015). 'A New Criterion for Assessing Discriminant Validity in Variance-based Structural Equation Modeling', Journal of the Academy of Marketing Science, 43, pp. 115-135.

Hofstede, G. (1980). Culture's consequences. Beverly Hills: Sage. 
Hulland, J. (1999). 'Use of Partial Least Squares (PLS) in Strategic Management Research: A Review of Four Recent Studies', Strategic Management Journal, 20, pp. 195-20.

Johansson, J. K. and G. S. Yip (1994). 'Exploiting Globalization Potential: U.S. and Japanese Strategies', Strategic Management Journal, 15, pp. 579-601.

Jormanainen, I. and A. Koveshnikov (2012). 'International Activities of Emerging Market Firms A Critical Assessment of Research in Top International Management Journals', Management International Review, 52, pp. 691-725.

Kale, P. (2009). 'The Global Indian Firm: Growth Value Creation through Overseas Acquisitions', The Indian Journal of Industrial Relations, 45, pp. 41-53.

Kedia, B., N. Gaffney and J. Clampit (2012). 'EMNEs and Knowledge-seeking FDI', Management International Review, 52, pp. 155-173.

Khan, Z. and J. D. Nicholson (2014). 'An investigation of the cross-border supplier development process: Problems and implications in an emerging economy', International Business Review, 23, pp. 1212-1222.

Kogut, B. and H. Singh (1988). 'The effect of national culture on the choice of entry mode', Journal of International Business Studies, 19, pp. 411-432.

Kogut, B. and U. Zander (1992). 'Knowledge of the firm, combinative capabilities, and the replication of technology', Organization Science, 3, pp. 383-397.

Kogut, B. and U. Zander (1993). 'Knowledge of the firm and the evolutionary theory of the Multinational Corporation', Journal of International Business Studies, 24, pp. 625-645. 
Lee, H. and B. Choi (2003). 'Knowledge management enablers, processes, and organizational performance: an integrative review and empirical examination', Journal of Management Information Systems, 20, pp. 179-228.

Li, L. (2005). 'The effects of trust and shared vision on inward knowledge transfer in subsidiaries' intra- and inter-organizational relationships', International Business Review, 14, pp. 77-95.

Li, L., W. Barner-Rasmussen and I. Bjorkman (2007). 'What Difference Does the Location Make?: A Social Capital Perspective on Transfer of Knowledge from Multinational Corporation Subsidiaries Located in China and Finland', Asia Pacific Business Review, 13, pp. 233-249.

Luo, Y. and R. L. Tung (2007). 'International expansion of emerging market enterprises: A springboard perspective', Journal of International Business Studies, 38, pp. 481-498.

Lyles, M. A. and J. E. Salk (1996). 'Knowledge Acquisition from Foreign Parents in International Joint Ventures: An Empirical Examination in the Hungarian Context', Journal of International Business Studies, 27, pp. 877-903.

Mahnke, V., T. Pedersen and M. Venzin (2005). 'The Impact of Knowledge Management on MNC Subsidiary Performance: The Role of Absorptive Capacity', Management International Review, 2, pp. 101-119.

Mathews, J. A. (2006). 'Dragon multinationals: New players in 21st century globalization', Asia Pacific Journal of Management, 23, pp. 5-27. 
McGuinness, M., Demirbag, M., and Bandara, S. (2013) Towards a multi-perspective model of reverse knowledge transfer in multinational enterprises: A case study of Coats plc, European Management Journal, 32, 2, pp.179-195.

Minbaeva, D. B. (2005). 'HRM practices and MNC knowledge transfer', Personnel Review, 34, pp. 125-144.

Minbaeva, D. B., T. Pedersen, I. Bjorkman, C. F. Fey and H. J. Park (2003). 'MNC knowledge transfer, subsidiary absorptive capacity, and HRM', Journal of International Business Studies, 34, pp. 586-599.

Monteiro, L. F., N. Arvidsson and J. Birkinshaw (2008). 'Knowledge Flows within Multinational Corporations: Explaining Subsidiary Isolation and Its Performance Implications', Organization Science, 19, pp. 90-107.

Mudambi, R. (2002). 'Knowledge management in multinational firms', Journal of International Management, 8, pp. 1-7.

Mudambi, R., L. Piscitello and L. Rabbiosi (2014). 'Reverse Knowledge Transfer in MNEs: Subsidiary Innovativeness and Entry Modes', Long Range Planning, 47, pp. 49-63.

Muthusamy, S. K. and M. A. White, (2005). 'Learning and Knowledge Transfer in Strategic Alliances: A Social Exchange View', Organization Studies, 26, pp. 415-441.

Nahapiet, J. and S. Ghoshal, (1998). 'Social capital, intellectual capital, and the organizational advantage', Academy of Management Review, 23, pp. 242-66. 
Nair, S. R. and Demirbag, M. (2015). 'Indian Multinationals: Location Choices of Overseas Mergers and Acquisitions'. In Demirbag, M. and Yaprak, A. (eds), Handbook of Emerging Market Multinational Corporations, pp. 154-182. MA: Edward Elgar.

Najafi-Tavani, Z., A. Giroud and R. R. Sinkovics (2012). 'Mediating Effects in Reverse Knowledge Transfer Processes -The Case of Knowledge-Intensive Services in the U.K', Management International Review, 52, pp. 461-488.

Nayyar, D. (2008). 'The Internationalisation of Firms from India: Investment, Mergers and Acquisitions', Oxford Development Studies, 36, pp. 111- 131.

Nelson, R. and S. G. Winter (1982). An evolutionary theory of economic change. Cambridge, MA: Belknap Press.

Newell, S., C. Tansley and J. Huang (2004). 'Social Capital and Knowledge Integration in an ERP Project Team: The Importance of Bridging and Bonding', British Journal of Management, 15, pp. 43-57.

Nonaka, I. (1991). 'The knowledge-creating company', Harvard Business Review, 69, pp. 96-104.

Nonaka, I. (1994). ‘A dynamic theory of knowledge creation', Organization Science, 5, pp. 14-37.

Nonaka, I. and G. Von Krogh (2009). 'Perspective-tacit knowledge and knowledge conversion: Controversy and advancement in organizational knowledge creation theory', Organization science, 20, pp. 635-652. 
Nonaka, I. and H. Takeuchi (1995). The Knowledge Creating Company: How Japanese Companies Create the Dynamics of Innovation. New York: Oxford University Press.

Nonaka, I., D. Umemoto and D. Senoo (1996). 'From information processing to knowledge creation: A paradigm shift in business management', Technology in Society, 18, pp. 203-218.

Nunnally, J. (1978). Psychometric theory. McGraw-Hill: New York.

Park, C., I. Vertinsky and M. Becerra (2015). 'Transfers of tacit vs. explicit knowledge and performance in international joint ventures: The role of age', International Business Review, 24, pp. 89-101.

Pereira, V., S. Munjal and M. K. Nandakumar (2016). 'Reverse dependency: a longitudinal case study investigation into Headquarter-Subsidiary relationship in the context of an emerging country'. International Studies of Management \& Organization, 46, pp. 50-62.

Perez-Nordtvedt, L., B. L. Kedia, D. K. Datta and A. A. Rasheed (2008). 'Effectiveness and Efficiency of Cross-Border Knowledge Transfer: An Empirical Examination', Journal of Management Studies, 45, pp. 714-744.

Persson, M. (2006). 'The impact of operational structure, lateral integrative mechanisms and control mechanisms on intra-MNE knowledge transfer', International Business Review, 15, pp. 547-569.

Podsakoff, P. M., S. B. MacKenzie, J. Y. Lee and N. P. Podsakoff (2003). 'Common method biases in behavioural research: A critical review of the literature and recommended remedies', Journal of Applied Psychology, 88, pp. 879-903.

Polanyi, M. (1962). Personal Knowledge. Chicago: University of Chicago Press. 
Polyani, M. (1966). The Tacit Dimension. London: Routledge.

Pradhan, J. P. (2007). Trends and Patterns of Overseas Acquisitions by Indian Multinationals, MPRA Paper, http://mpra.ub.uni-muenchen.de/12404/.

Prahalad, C. K. and G. Hamel (1990). 'The core competence of the corporation', Harvard Business Review, 68, pp. 79-91.

Rabbiosi, L. (2011). 'Subsidiary roles and reverse knowledge transfer: An investigation of the effects of coordination mechanisms', Journal of International Management, 17, pp. 97113.

Rabbiosi, L. and G. D. Santangelo (2013). 'Parent company benefits from reverse knowledge transfer: The role of the liability of newness in MNEs', Journal of World Business, 48, pp. $60-170$.

Reber, A. S. (1993). Implicit Learning and Tacit Knowledge. New York: Oxford University Press.

Reed, R. and R. J. DeFillippi (1990). 'Causal ambiguity, barriers to imitation, and sustainable competitive advantage', Academy of management review, 15, pp. 88-102.

Richey, R. G. and C. W. Autry (2009). 'Assessing interfirm collaboration/technology investment tradeoffs - The effects of technological readiness and organizational learning', The International Journal of Logistics Management, 20, pp. 30-56.

Ringle, C. M., M. Sarstedt and D. W. Straub (2012). 'A Critical Look at the Use of PLS-SEM in MIS Quarterly', MIS Quarterly, 36, pp. iii-xiv. 
Ringle, C. M., S. Wende and J-M. Becker (2015). SmartPLS 3. Bonningstedt: SmartPLS. Retreived from http://www.smartpls.com.

Schulz. M. (2001). 'The Uncertain Relevance of Newness: Organizational Learning and Knowledge Flows', The Academy of Management Journal, 44, pp. 661-681.

Sethi, D. (2009). 'Are multinational enterprises from the emerging economies global or regional?', European Management Journal, 27, pp. 356-365.

Simonin, B. L. (1999). 'Ambiguity and the Process of Knowledge Transfer in Strategic Alliances’, Strategic Management Journal, 20, pp. 595-623.

Simonin, B. L. (2004). 'An empirical investigation of the process of knowledge transfer in international strategic alliances', Journal of International Business Studies, 35, pp. 407-27.

Simonin, B. L. and A. S. Ozsomer (2009). 'Knowledge Processes and Learning Outcomes in MNCs: An Empirical Investigation of the Role of HRM Practices in Foreign Subsidiaries', Human Resource Management, 48, pp. 505-530.

Spender J.-C. and R. M. Grant (1996). 'Knowledge and the Firm: Overview', Strategic Management Journal, 17, pp. 5-9.

Szulanski, G. (1996). 'Exploring Internal Stickiness: Impediments to the Transfer of Best Practice within the Firm', Strategic Management Journal, 1, pp. 27-43.

Szulanski, G., R. Cappetta and R. J. Jensen (2004). 'When and How Trustworthiness Matters: Knowledge Transfer and the Moderating Effect of Causal Ambiguity', Organization Science, 15, pp. 600-613. 
Thite, M., A. Wilkinson, P. Budhwar and J. A. Mathews (2015). 'Internationalization of emerging Indian multinationals: Linkage, leverage and learning (LLL) perspective'. International Business Review, 25, pp. 435-443.

Tran, Y., V. Mahnke and B. Ambos (2010). 'The Effect of Quantity, Quality and Timing of Headquarters-initiated Knowledge Flows on Subsidiary Performance', Management International Review, 50, pp. 493-511.

Tsai, W. and S. Ghoshal (1998). 'Social capital and value creation: the role of intrafirm networks', Academy of Management Journal, 41, pp. 464-476.

Van Wijk, R., J. J. P. Jansen and M. A. Lyles (2008). 'Inter- and intra-organizational knowledge transfer: A meta-analytic review and assessment of its antecedents and consequences', Journal of Management Studies, 45, pp. 830-853.

von Hippel, E. (1994). 'Sticky information and the locus of problem solving: Implications for innovation', Management Science, 40, pp. 429-439.

Whelan, E., S. Parise, J. De Valk \& R. Aalbers (2011). 'Creating Employee Networks That Deliver Open Innovation', MIT Sloan Management Review, 53, pp. 37-44.

Wilkinson, A., G. T. Wood and M. Demirbag (2014). 'Guest editors' introduction: People management and emerging market multinationals', Human Resource Management, 53, pp. $835-849$.

Williams, C. (2009). 'Subsidiary-level determinants of global initiatives in multinational corporations', Journal of International Management, 15, pp. 92-104. 
Winter, S. (1987). 'Knowledge and competence as strategic assets'. In D. Teece (eds), The Competitive Challenge - Strategies for Industrial Innovation and Renewal, pp. 159-184, Cambridge, MA: Ballinger.

Yamao, S., H. de Cieri and K. Hutchings (2009). 'Transferring subsidiary knowledge to global headquarters: Subsidiary senior executives' perceptions of the role of HR configurations in the development of knowledge stocks', Human Resource Management, 48, pp. 531-554.

Yang, Q., R. Mudambi and K. E. Meyer (2008). 'Conventional and Reverse Knowledge Flows in Multinational Corporations', Journal of Management, 34, pp. 882-902.

Yli-Renko, H., E. Autio and V. Tontti (2002). 'Social capital, knowledge, and the international growth of technology-based new firms', International Business Review, 11, pp. 279-304.

Zander, U. and B. Kogut (1995). 'Knowledge and the Speed of the Transfer and Imitation of Organizational Capabilities: An Empirical Test', Organization Science, 6, pp. 76-92.

Zhao, Z. J. and J. Anand (2009). 'A multilevel perspective on knowledge transfer: Evidence from the Chinese automotive industry', Strategic Management Journal, 30, pp. 959-983. 